\title{
OCULAR METASTASIS AS FIRST PRESENTATION OF RENAL CELL CARCINOMA: REPORT OF 2 CASES
}

\author{
Antonio Carlos Lima Pompeu, Sami Arap, Matheus Neves R. Silva and Daniel S. \\ Monteiro
}

POMPEU ACL et al. Ocular metastasis as first presentation of renal cell carcinoma: Report of 2 cases. CLINICS 60(1): 75-78, 2005.

Authors report the cases of 2 patients who had an ocular lesion as the first sign leading to diagnosis of renal cell carcinoma, an uncommon presentation of this neoplasm.

The first patient was a 59-year-old man presented with a mass in the right eye. The histological and immunohistochemical profile of the biopsy showed a probable renal cell carcinoma. A CT scan showed a solid mass in the left kidney. The patient underwent radical nephrectomy and excision of the ocular lesion and had an uneventful evolution. The second patient was a 72-year-old man presenting with an ulcerated lesion on the right inferior tarsal conjunctiva. An excisional biopsy of the lesion showed histological and immunohistochemical patterns of a clear cell carcinoma. Abdominal tomography disclosed a right peripheral renal tumor. A right radical nephrectomy was performed.

Renal cell carcinoma may present atypically with metastases to quite uncommon organs. Nephrectomy may be of value in selected cases; the ocular metastases are usually excised for aesthetic and functional reasons.

KEYWORDS: Renal tumor. Metastasis. Ocular metastasis. Eye. Renal neoplasm.

Renal cell carcinoma accounts for approximately $85 \%$ of primary renal neoplasms, ${ }^{1}$ and represents approximately $3 \%$ of all adult malignancy. ${ }^{2}$ The most common sites of metastasis are lung $(50 \%)$ and bone $(33 \%)$, but renal cell carcinoma has been documented to metastasize to every organ and site in the body. Only rarely does it metastasize to the eye and orbit, occasionally mimicking other lesions. ${ }^{3}$ Moreover, considering all metastatic neoplasms in the eye, only a minority is due to renal cell carcinoma, as demonstrated in a pathology survey where only 7 out of 196 cases of ocular metastatic carcinoma originated from renal cell carcinomas. ${ }^{4}$ Ocular metastases from renal cell carcinomas are most like to involve the iris, ${ }^{5}$ ciliary body, ${ }^{6}$ and choroids, although eyelid and orbital metastases have been de-

From the Urology Service, Department od Surgery, Hospital das Clínicas, Faculty of Medicine, University of São Paulo - São Paulo/SP, Brazil.

E-mail: ribeiromed@hotmail.com

Received for publication on August 18, 2004.

Accepted for publication on October 15, 2004. scribed. $^{7}$ Our aim is to report 2 cases of patients who had an ocular lesion as the first sign leading to diagnosis of renal cell carcinoma.

\section{CASE 1}

A 59-year-old man presented to the outpatient ophthalmology department of our hospital in June 2003 with a 3month history of diplopia and a mass in the right eye. His medical history was significant only for hypertension. Upon examination, a conjunctival lesion and proptosis were found (Figure 1). A CT scan and an ocular ultrasound examination revealed a retroocular mass inferior to the optical nerve. The diagnostic impression on clinical and radiological findings was of a probable metastatic neoplasm. A thoracic CT scan revealed multiple nodular lesions, and an abdominal ultrasound showed a mass in the inferior pole of left kidney and subhepatic lymphadenopathy. The results of complete blood count, electrolytes, liver function tests, 


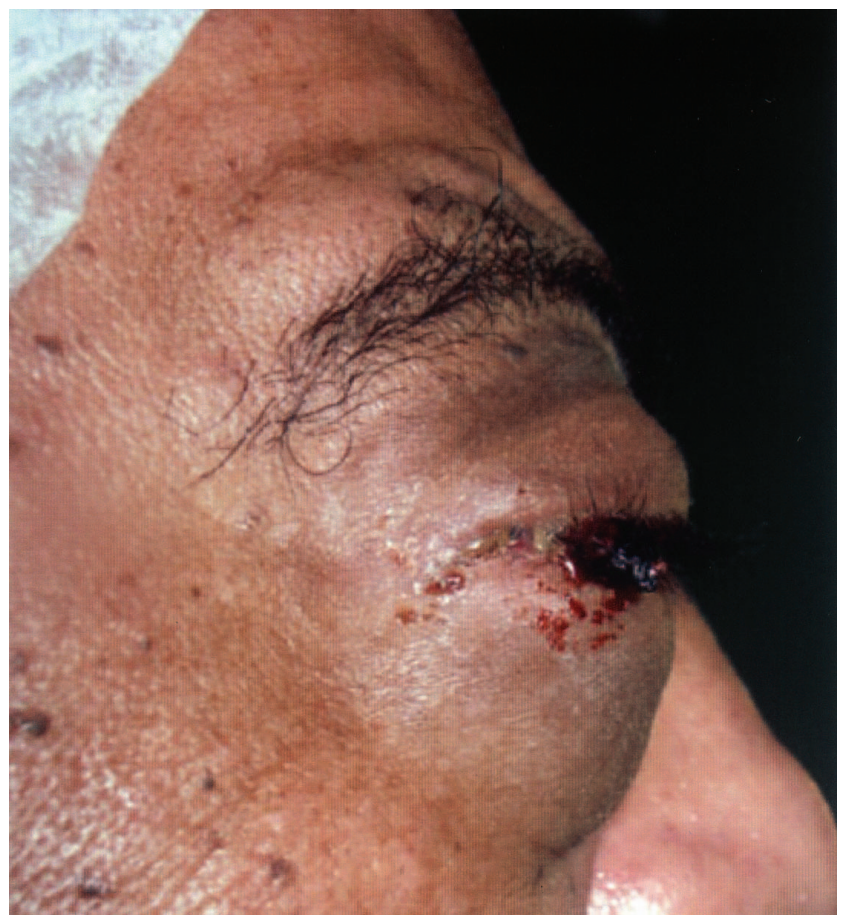

Figure 1 - A 59-year-old man with proptosis and a conjunctival lesion protruding through the palpebral fissure.

and tumor markers were all normal, except for a total serum PSA, which was 4.7. A 12-fragment biopsy of the prostate was performed, disclosing only benign prostatic hyperplasia, chronic unspecific prostatitis, and an atypical proliferation of small acini. Biopsy of the right inferior rectus muscle was suggestive of metastatic adenocarcinoma. The immunohistochemical profile revealed a probable renal cell carcinoma.

The patient was then referred for urological evaluation. The urological history was notable for hematuria 1 year previously with spontaneous remission and occasional episodes of flank pain. On examination, a hard, large mass was palpable in the left flank. Abdominal CT showed a large solid mass involving the inferior pole and mid portion of left kidney (Figure 2). A radical nephrectomy was performed, and the patient discharged in the sixth postoperative day. Macroscopically, the tumor involved almost the entire parenchyma. Histological analysis revealed a tubulopapilar renal tumor, with a predominance of clear cells. The conjunctival lesion was excised for aesthetic and functional reasons; at histology the lesion was found to be a renal cell carcinoma.

\section{CASE 2}

In 1996, a 72-year-old man presented for ophthalmologic evaluation of a 6-mm ulcerated lesion on the right

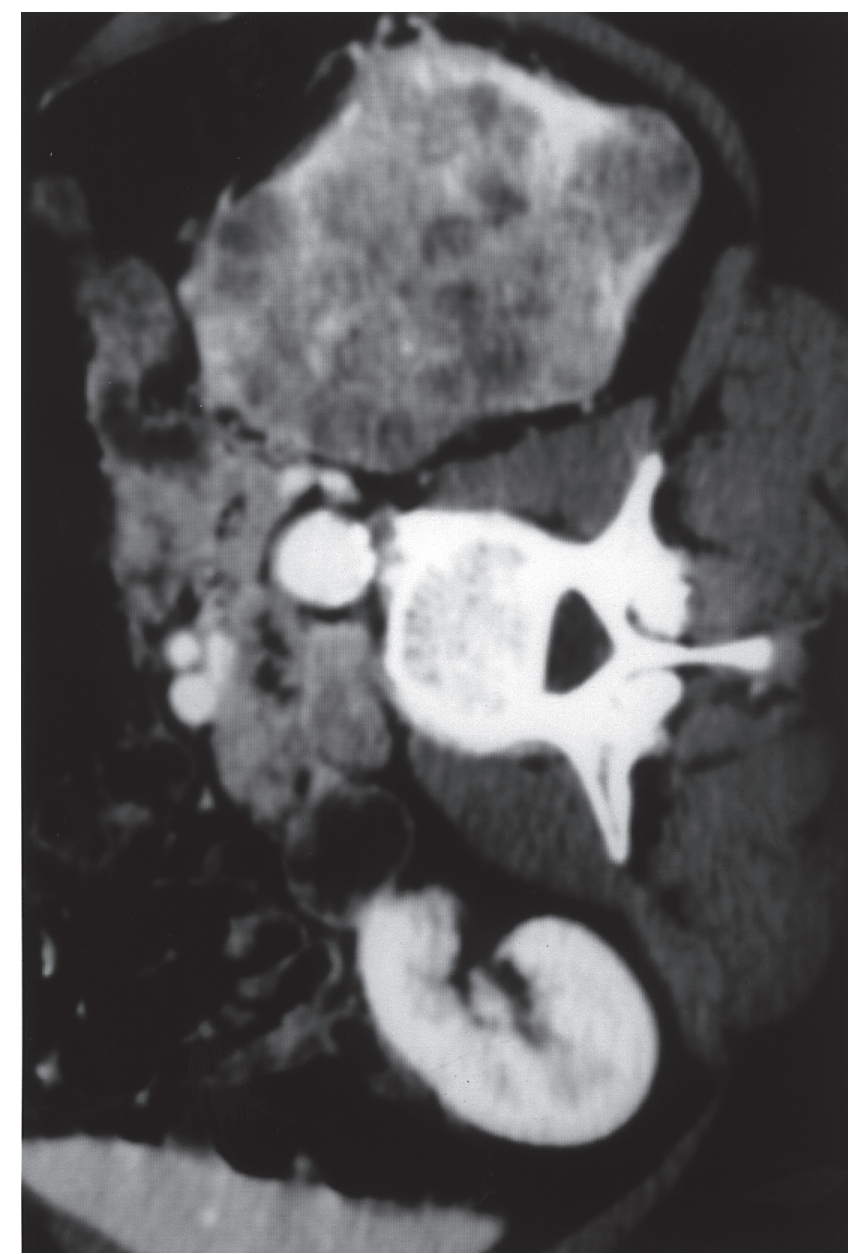

Figure 2 - Computed tomography of the abdomen revealed a large solid mass involving the inferior pole and mid portion of left kidney, infiltrating the perirenal fat, and in close contact with the psoas muscle.

inferior tarsal conjunctiva associated with no other ophthalmologic symptoms. An excisional biopsy of the lesion showed histological and immunohistochemical patterns of a clear cell carcinoma.

At urological evaluation, the patient had only mild obstructive urinary symptoms. His medical history was negative for any other disease. On physical examination, no abdominal or flank mass could be palpated. Prostatic examination revealed a slight benign increase in its size with no nodules or induration. Serum laboratory was entirely normal. An abdominal tomography disclosed a 6-cm right peripheral renal tumor without evidence of intraabdominal metastasis. A thoracic CT scan and a radionuclide bone scan revealed no metastases. The patient underwent a right radical nephrectomy. Microscopically, there was only 1 perihilar lymph node with neoplastic disease. Three years later before the patient was lost to follow-up, no evidence of recurrence was present. 


\section{DISCUSSION}

Renal cell carcinomas represent approximately $3 \%$ of all adult malignancies and usually occur in men between the ages of 30 and 60 years. ${ }^{8}$ Metastases commonly occur, with about $40 \%$ of patients presenting with metastatic disease. The most frequent metastatic sites are lung (76\%), regional lymph nodes $(66 \%)$, bone $(42 \%)$, and liver $(41 \%) .{ }^{9}$ Ocular metastases from renal cell carcinoma have been reported as uncommon, ${ }^{3}$ even though the actual incidence is not known.

Renal cell carcinoma is characterized by a variety of clinical features. The natural history is highly variable, with metastases presenting as the sign leading to the diagnosis of the renal malignancy; alternatively, metastases may present decades after the removal of the primary disease..$^{10,11}$ Other features include a diverse set of clinical manifestations and a relatively poor response to radiation therapy and chemotherapy. ${ }^{12}$ In the 2 cases in the present report, the ocular metastasis was the initial presenting sign that led to the diagnosis of renal malignancy, in contrast to some reports of the ocular metastasis appearing years after the nephrectomy, even 20 years later. ${ }^{3}$

The survival of patients with renal cell carcinoma is re- lated most closely to the pathologic stage of the disease. ${ }^{12}$ In patients who initially present with metastatic disease, nephrectomy is performed in selected patients with solitary or low-volume resectable metastasis, ${ }^{13}$ as in our second case, and those with local symptoms, as in our first patient who had flank pain. Renal cell carcinoma responds relatively poorly to standard chemotherapeutic agents. ${ }^{12.13}$ Patients treated with biological response modifiers such as interleukin-2, interferon alpha, beta, or gamma, or a combination of agents may show a complete or partial response ( $<20 \%$ of patients). The treatment of ocular metastasis may aim for cure when it represents a solitary metastasis, or may be excised for aesthetic and functional reasons in cases of more advanced disease. ${ }^{14}$ In the 2 patients reported herein, the ocular metastases were treated successfully by surgery, whereas some authors suggest the use of radiotherapy. ${ }^{3}$

These 2 cases were illustrative that renal cell carcinoma may have atypical presentations with metastases to quite uncommon organs. Even in cases of advanced disease, nephrectomy may be of value, rendering the patient symptom-free. The treatment of ocular metastasis is usually necessary for aesthetic, or functional reasons, even when a cure is no longer achievable.

\section{RESUMO}

POMPEU ACL e col. Metástase ocular como apresentação inicial de carcinoma de células renais: Relato de dois casos. CLINICS 60 (1):75-78, 2005.

Os autores apresentam dois casos de metástase ocular como o primeiro sinal que levou ao diagnóstico de carcinoma renal, uma apresentação incomum desta neoplasia.

O primeiro paciente era um homem de 59 anos com uma massa no olho direito. O perfil histológico e imunohistoquimico demonstraram um provável carcinoma de células renais. A tomografia computadorizada revelou uma massa sólida no rim esquerdo, e o paciente foi submetido a nefrectomia radical esquerda, apresentando uma evolução sem complicações. O segundo paciente era um homem com
72 anos portador de uma lesão ulcerada na conjuntiva tarsal inferior direita. Uma biopsia excisional da lesão demonstrou um padrão histológico e imunohistoquimico de carcinoma de células renais. A tomografia de abdômen demonstrou um tumor periférico em rim direito, sendo o paciente submetido a nefrectomia radical.

O carcinoma de células renais pode se apresentar atipicamente com metástases para órgãos incomuns. Nefrectomia pode ser útil em casos selecionados. As metástases oculares geralmente são excisadas por razoes estéticas e funcionais.

UNITERMOS: Tumor renal. Metástase. Metástase ocular. Olho. Neoplasia renal. 


\section{REFERENCES}

1. Garnick MB, Richie JP. Primary neoplasms of the kidney and renal pelvis. In: Schrier RW, Gottschalk CW. Disease of the kidney. $5^{\text {th }}$ ed. Boston: Little, Brown, 1993, vol 1. chap 29.

2. deKernion, JB; Belldegrun, A. Renal tumors. In Walsh, PC; Retil $A B$; Vaughan ED Jr, editors. Campbell's Urology, $6^{\text {th }}$ ed. Philadelfia: WB Saunders, 1992:10053-93.

3. Haimovici R, Gragoudas ES, Gregor Z. Choroidal metastases from renal cell carcinoma. Ophtalmol 1997;104(7):1152-8.

4. Ferry AP, Font RL. Carcinoma metastatic to eye and orbit: a clinicopathologic study of 27 cases. Ophtalmol 1974;92:27686.

5. Wizinski P, Rootman J, Wood W. Simultaneous bilateral iris metastases from renal cell carcinoma. Am J Optalmol 1981;92:206-9.

6. Laszczyk WA. Metastatic tumor of the ciliary bodyhypernephroma. Ophtalmologica 1975;170:543-7.

7. Kindermann WR, Shields JA, Eiferman RA. Metastatic renal cell carcinoma to the eye and adnexae: a report of three cases and review of the literature. Ophtalmol 1981;88:1347-50.
8. Simo, R; Sykes, AJ; Hargeaves, SP. Metastatic renal cell carcinoma to the nose and paranasal sinuses. Head Neck 2000;74:722-7.

9. Reese, DM; Corry, M; Small, EJ. Infusional floxuridine-based therapy for patients with metastatic renal cell carcinoma. Cancer 2000; 88:1310-6.

10. Walter CW, Gillespie DR. Metastatic hypernephroma of fifty years duration. Minn Med 1960;43:123-5.

11. Tandon PL, Kumar M, Hafezz Ma. Metastasis from renal cell carcinoma twenty years after nephrectomy: a case report. Br J Urol 1963;35:30-2.

12. Motzer RJ, Bander NH, Nanus DM. Renal cell carcinoma. N Engl J Med 1996;335:865-75.

13. Weingensberg IJ. Metastatic renal cell carcinoma: unusual and deceptive presenting features. South Med J 1972;65:611-6.

14. Whraram MD Jr, Schachat AP. Choroidal metastasis. In: Ryan SJ, editor. Retina. St Louis: C.V. Mosby, 1989; v. 1, chap 50. 